\title{
PAGES IN THE ANTARCTIC
}

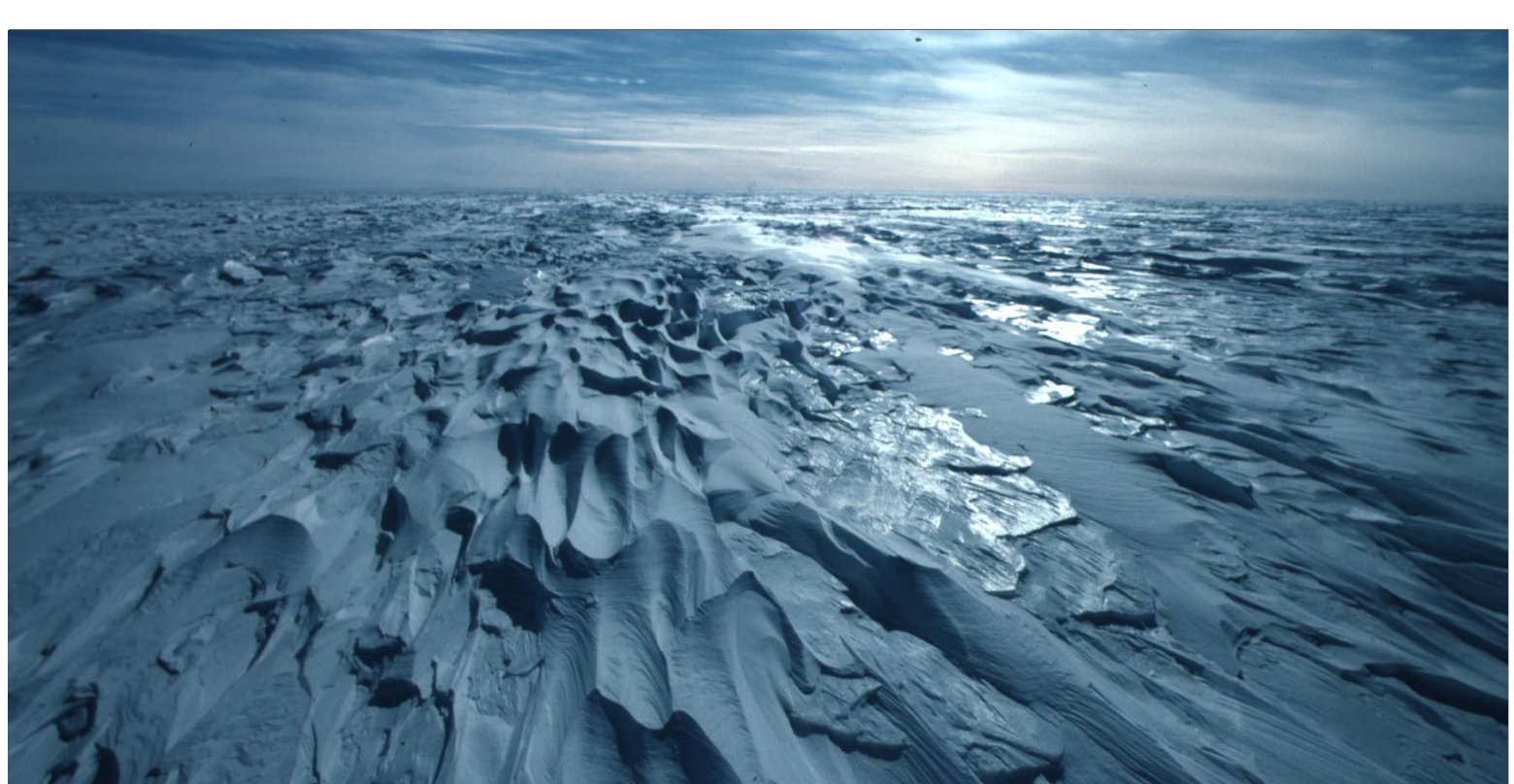

The Global Change and the Antarctic (GLOCHANT) Programme of the Scientific Committee on Antarctic Research (SCAR) co-sponsors three programmes with PAGES, on Antarctic climate and environmental history.

These palaeoclimate and palaeoenvironment programmes are focused on the last 200,000 years, as recorded in deep ice cores (Palaeoenvironments from Ice Cores (PICE) programme), circum-Antarctic onshore and offshore sediments (Late Quaternary Sedimentary Record of the Antarctic Ice Margin Evolution (ANTIME) programme). A high resolution history covering the last 200-500 years and the period of greatest anthropogenic change, is the focus of the shallow to medium depth ice cores (International Trans-Antarctic Scientific Expedition (ITASE) programme).

\section{ITASE}

\section{Years of Past Antarctic Climate and Environmental Change}

Cambridge, UK, August 2-3, 1996

As a consequence of this international meeting a science and implementation plan has recently been completed and published in the PAGES Workshop Report, Series 97-1. The ITASE Executive Summary is reproduced below.

Copies of the report can be obtained from the PAGES Office, or the SCAR Global Change Programme Office, Antarctic CRC GPO Box 252-80, Hobart 7001 Tasmania, Australia.

\section{ITASE Science and Implementation Plan Executive Summary}

From its original formulation in 1990 the International Trans Antarctic Scientific Expedition (ITASE) has had as its primary aim the collection and interpretation of a continental-wide array of environmental parameters assembled through the coordinated efforts of scientists from several nations.

\section{PAGES activities in the Antarctic (lan Goodwin)}

Editorial: Recent ENSO anomalies, natural variability and anthropogenic effects (R. Bradley)

News from PEP III

Workshop reports (LBA, LUCC/IGBP-DIS)

Activities of PAGES lake drilling task force (S. Colman)

PAGES calendar

Upcoming workshops: PEP 1, agenda of the meting; Chapman Conference, conference scope

Draft program, change in the venue and general information (see also http://www.pages.unibe.ch/) 


\section{EDITORIAL}

Do

recent ENSO anomalies reflect natural variability or anthropogenic effects - or both?

$T_{\text {h }}$ he strong El Niño event which developed in 1997 has wrought havoc in many parts of the world - floods in Ecuador and Peru, unusually intense and frequent landfall of hurricanes in Mexico, drought and forest fires in Indonesia and Malaysia and heavy rainfall in the south-western United States. Satellite-based sensors reveal the enormous area of positive sea surface temperature anomalies which developed in the eastern Equatorial Pacific in the latter half of 1997 (see http://www.ogp.noaa.gov/enso) raising the question: how unusual is this situation? Satellite observations are recent and provide only a limited temporal perspective on the current event. A longer-term view is provided by the Southern Oscillation Index (SOI) which is based on the sea-level pressure difference between Tahiti and Darwin. The series extends back reliably to 1935 and although the discovery of early pressure data from Tahiti allowed a century-long series to be constructed (Ropelewski \& Jones 1987) doubts have been raised about the reliability of these data (Trenberth 1997). Darwin pressure data appear to be more homogenous, but they can only provide a limited perspective on the overall complexity of the large-scale ENSO System. However, in spite of their limitations, all of these records point to the 1997-98 El Niño event as truly extraordinary - comparable in magnitude to the "previous record" of 1982-83, but with a different temporal evolution of the anomaly field. Furthermore, the current El Niño comes on the heels of a sequence of warming events, spanning much of the period from 1990 1995 (Goddard \& Graham, 1997); indeed, since 1976 there have been relatively few cold events and many more warm events suggesting to some that there has been a fundamental change in the climate system, brought about by anthropogenic increases in greenhouse gases. According to Trenberth \& Hoar $(1996,1997)$ the sequence of 22 positive seasoned sea-level pressure anomalies at Darwin from 1990-95 (relative to the 1882-1981 mean) and their large magnitude, implies a return period of approximately 8850 years. They argue that such an occurrence is unlikely to be entirely due to natural variability and that anthropogenic effects are implicated. However, Rajagopalan et al. (1997) re-examine this claim using a non-parametric statistical analysis and conclude that the return period for such a sequence of anomalies is very sensitive to the statistical model applied to the data and to the reference period selected. In particular, because climate sensitivity in the Tropics consists of inter-annual, inter-decadal and lower frequency (centennial-scale) modes (Mann \& Park 1994; Latif et al. 1997; Zhang et al. 1997) the calculation of ENSO return periods is a particularly difficult task when records are short. Accordingly, Rajagopalan et al. (1997) show that the 1990-95 run of positive anomalies can be viewed as having a return period ranging anywhere from 79 to 3250 years, depending on the record length and model selected.

High resolution paleoclimatic data can shed light on this controversy. Geochemical studies of banded corals have demonstrated they are extremely good proxies of intra-annual changes in SST and/or rainfall in the tropics. The PAGES 'ARTS' project (Annual Records of Tropical Systems) focuses on using such records together with tree-rings, low latitude ice cores and varved sediments to reconstruct multi-century length records of tropical climatic conditions. Research focuses on extracting reliable records of climate variability, ranging from inter-annual to century timescales. By extending the record of tropical climate variability back in time, and expanding the spatial coverage of data across the Tropics, a more comprehensive view of the spatio-temporal variability of ENSO events will be obtained. Until this happens, arguments over whether recent conditions in the Pacific are attributed to natural variability of or anthropogenic effects (or both) will be difficult to resolve.

(See page 4 for references)

RAY BRADLEY

Chairman, PAGES SSC (continued from page 1)

Because of the remoteness of the continent, Antarctica is an ideal location to monitor biogeochemical cycles and local-to-global scale climate change. However, this remoteness has also prevented the collection of instrumental records, similar to those collected in the northern hemisphere, that are required to assess Antarctica's role in and response to environmental and climate change.

As a consequence ITASE has been focused to address two key scientific objectives:

- To determine the spatial variability of Antarctic climate (eg. accumulation, air temperature, atmospheric circulation) over the last 200 years, and where the data are available the last 1000 years.

These variations include: major atmospheric phenomena such as ENSO; snow accumulation variations; and extreme events such as volcanic eruptions and storms.

- To determine the environmental variability in Antarctica over the last 200 yrs, and where the data are available the last 1000 years.

Environmental proxies could include: sea ice variation, ocean productivity, anthropogenic impacts; and other, extra-Antarctic continental influences.

In fulfilling these objectives ITASE will: produce continental scale "environmental maps"; elucidate transfer functions between components of the atmosphere and snow / ice; verify atmospheric models; and interpolate spatial time-series determined from satellite remote sensing. ITASE was adopted as a key science initiative by both the International Geosphere-Biosphere Program (IGBP) and the Scientific Committee on Antarctic Research (SCAR). In August 1996 a SCAR/ GLOCHANT-IGBP/PAGES sponsored workshop was held to develop this Science and Implementation Plan for ITASE. Whilst the ITASE programme will focus on obtaining a spatially contiguous Antarctic palaeoclimatic and palaeoenvironmental data set for the last 200 years, longer records spanning the last 500-1000 years will also be retrieved on an opportunity basis. The combined palaeodata set will fill a significant void in our knowledge of Antarctic climate variability.

The ITASE programme is managed and coordinated through the SCAR Global Change Programme (GLOCHANT) Office, located at the Antarctic CRC in Hobart, Tasmania, Australia. All correspondence on planned and operational ITASE field traverses, firn/ice core analyses, and existing Antarctic palaeoclimatological and palaeo-environmental data banks should be made through the Programme Coordinator, Dr Ian Goodwin (e-mail: ian.goodwin@utas.edu.au). 


\section{Late Quatemary sedimentary record of Antarctic ice margin evolution}

Hobart, Australia, July, 6-11, 1997

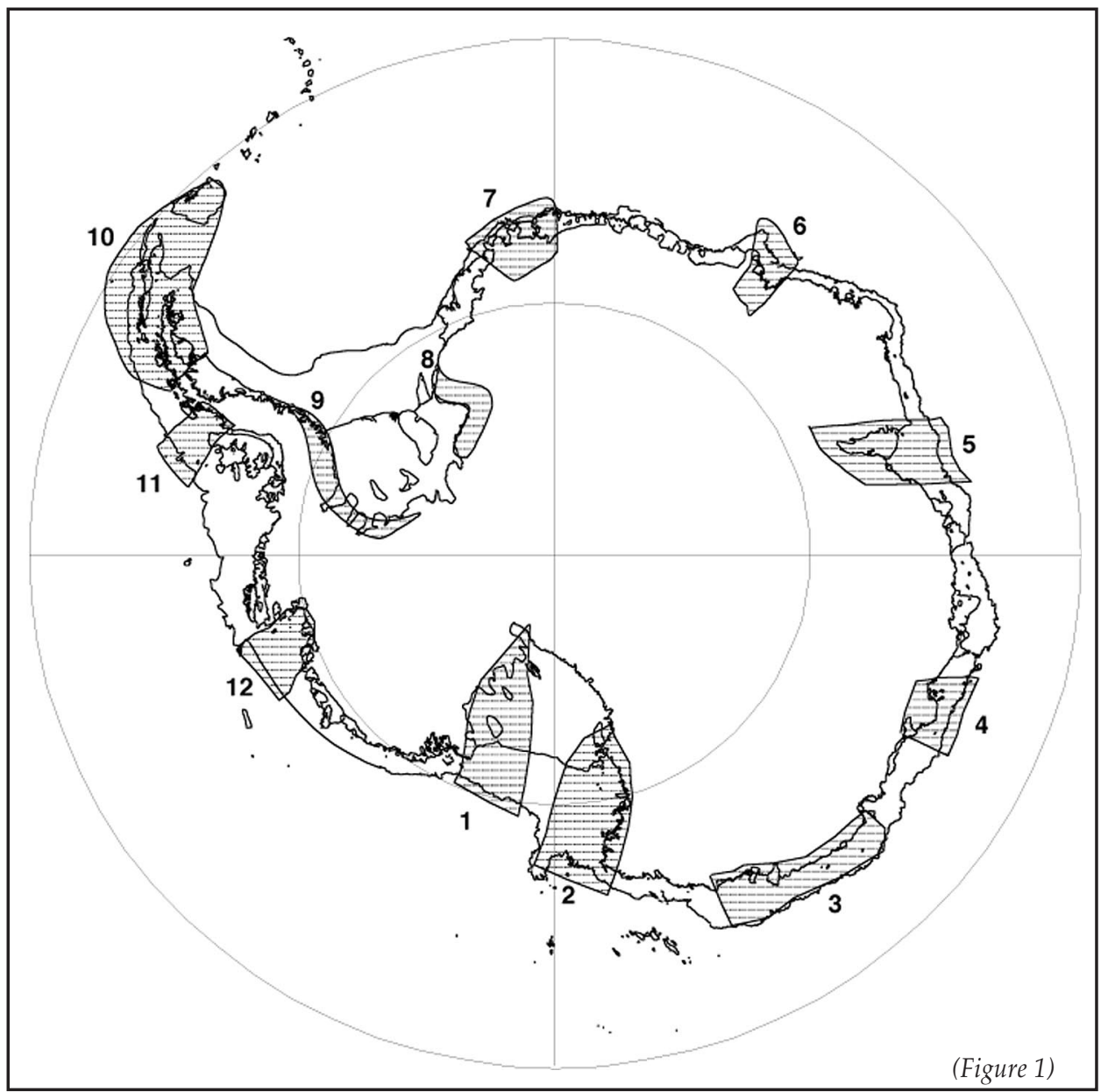

This first ANTIME workshop was held in parallel with the SCAR-ANTOSTRAT (Antarctic Offshore Stratigraphy) workshop. There were 65 participants from Australia, USA, UK, Italy, Spain, Japan, Sweden, Germany and Russia. The participants included representatives of PAGES, IMAGES, INQUA and the International Arctic Science Committee (IASC).

The workshop included three scientific sessions on:

- Extent, timing and regional differences during Glacial Stage 2 (10-30 kyr BP) in Antarctica, from the terrestrial and marine records;

- Climatic, environmental and glacial events during the Holocene;

- Late Quaternary geochronological problems in Antarctica.

An abstract volume was published prior to the workshop. The participants agreed to prepare a special issue of the Antarctic Science on the most recent developments in Late Quaternary research in Antarctica. The journal
A framework for an ANTIME Science and Implementation Plan was developed at the workshop. The plan is currently in development and should be published towards the end of 1998.

\section{ANTIME Priority Research}

The workshop participants recognised that there was an immediate need to depict the present status of knowledge on the maximum extent of the Antarctic Ice Sheet during the last Glacial cycle, and the nature of the retreat to the present ice sheet margins. It was agreed that this should be completed for priority regions, which characterised the range of ice morphologies and climatologies that exist in the circum-Antarctic. These priority regions will also be used to plan future fieldwork and data correlation, and involve the linking of onshore glacial and coastal projects with marine projects on the continental shelf and slope, together with deep ocean coring projects administered through the IMAGES programme.

12 regional transects were selected as a priority for ANTIME research (Figure 1). Extensive data sets have already been collected in many of these regions, and future research is planned with national and/or international logistic support for each of these regions, over the period 1998 to 2003 . The transects comprise:

Region 1: Includes the Siple Coast and Siple Dome ice core record with the sedimentary record on the eastern Ross Sea continental shelf;

Region 2: Consits of glacial and coastal records in Victoria Land, Transantarctic Mountains, western Ross Sea coast and continental shelf;

Region 3: Covers the sedimentary record from the coastal rock nunataks, promontories and islands, and continental shelf along George V Land, Adelie Land and eastern Wilkes Land, from Cook Ice Shelf to Porpoise Bay;

Region 4: Includes the Law Dome ice core record, and the sedimentary record from coastal rock nunataks, promontories and islands along the Budd Coast together with the Vincennes Bay and Totten Glacier embayments on the continental shelf;

Region 5: Includes sedimentary record from the Prince Charles Mountains, Amery Ice Shelf and Embayment, Vestfold Hills lakes and fjords, Prydz Bay, and the outer continental shelf where a series of Ocean Drilling Program (ODP) drill holes are planned for the 1999-2000 season;

Region 6: Links the ice core record at Dome Fuji with sedimentary record from the Lutzow-Holm Bay coast, and the continental shelf in the Cosmonaut Sea; 
Region 7: Links the sedimentary record in the Maudheimvidda, and offshore on the continental shelf in the Haakon VII Sea, with the potential ice core record from the planned EPICA ice cores;

Region 8: Links the sedimentary record in the Shackleton Mountains with the record in the Thiel Trough, Filchner Embayment and in the eastern Weddell Sea, together with the ice core record from Berkner Island;

Region 9: Covers the sedimentary record in the Ellsworth Mountains, and along the Orville and Lassiter Coasts,

Region 10: Covers the sedimentary record together with the Antarctic Peninsula ice core records from two transects; the eastwest meridional record across the Antarctic Peninsula in Graham Land, and; the north south zonal record along the Antarctic Peninsula from the South Orkney Islands, South Orkney Rise, South Shetland Islands, and down the Davis and Danco Coasts. A series of ODP drill cores is planned in the Palmer Deep from which a high resolution sedimentary record is expected to cover the Late Quaternary;

Region 11: Covers the sedimentary record from the eastern end of Alexander Island, with that from Marguerite Bay, and the continental shelf in the Bellingshausen Sea;

Region 12: Covers the sedimentary record from the inner continental shelf in the Pine Island Glacier trough, and offshore in the Amundsen Sea.
Research in these regions will include:

- the delineation of glacial extent and volume;

- the stratigraphy of glacial retreat;

- development of chronological control between continental shelf and onshore records;

- depiction of palaeo ice sheet and ice stream morphology, the relationship between ice sheets and continental shelf banks, and similarly between ice streams and shelf troughs;

- the interpretation of high resolution event stratigraphy for the Holocene, from: sedimentary investigations in lake, coastal, fjord, and shelf sequences; together with the high resolution ice core records from coastal ice domes.

A scientific advisory committee was selected for the ANTIME programme at the Hobart workshop, such that all national programmes and Antarctic sub-regions were represented. The nominated scientific advisory committee is as follows:

Prof. Eugene Domack, Hamilton College, USA, Co-Chairman,

Prof. Ross Powell, Northern Illinois University, USA, Co-Chairman,

Dr. Ian Goodwin, SCAR Global Change Programme/Antarctic CRC, Australia, ANTIME programme coordinator,

Prof. John Anderson, Rice University, USA, West Antarctic Ice Sheet (WAIS rep),

Dr. Paul Berkman, Ohio State University, USA,
Dr. Peter Harris, Antarctic CRC, Australia

Dr. Kazuomi Hirakawa, Hokkaido University, Japan,

Prof. Christian Hjort, Lund University, Sweden,

Dr. Mike Bentley, University of Edinburgh, UK,

Dr. Carol Pudsey, British Antarctic Survey, UK, ODP representative Antarctic Peninsula sector, Dr. Rainer Gersonde, Alfred Wegner Institute, Germany, ODP/IMAGES representative, Atlantic sector,

Dr. Will Howard, Antarctic CRC, Australia, ODP/IMAGES representative, Indian and Pacific sectors,

Dr. Miquel Canals, Universidad de Barcelona, Spain, and,

Dr. Marco Taviani, Instituto di Geologia Marina, Italy,

\section{ANTIME Workshop Abstract Volume}

Limited copies of the workshop abstract volume are available from the GLOCHANT office: Goodwin, I. D. (ed) 1997. Late Quaternary Sedimentary Record of the Antarctic Ice Margin Evolution (ANTIME), Workshop Abstracts, GLOCHANT-PAGES, Hobart, Australia, 6-11 July, 1997, 84 pp.

\section{Ian Goodwin}

SCAR - Antartic CRC, University of Tasmania, GPO Box 252-80, Hobart, 7001, AUSTRALIA

Tel: +61-3-6226 7544, Fax: +61-3-6226 7650, e-mail: lan.Goodwin@utas.edu.au

(continued from page 2 - Ray Bradley's editorial)

\section{References}

The Japanese Antarctic Research Expedition's (JARE) deep drilling project at Dome F (77¹9' 01" S, 39० 42' 12" E, 3,810 m) in central East Antarctica, has been completed over a 2 year period to a depth of 2,504 m. Ice core has been retrieved from the entire depth and analyses are in progress. The preliminary $\delta^{18} \mathrm{O}$ oxygen isotope analyses indicate that the core covers the last Glacial cycle back to $\sim 170,000$ years B.P. The preliminary results were presented at the Antarctica and Global Change Symposium held at the Antarctic CRC, Hobart, Tasmania, Australia, from 13-18 July, 1997. The results confirmed that the higher snow accumulation rate at Dome F site than at Vostok, will enable a potentially higher resolution palaeoclimatic record from Dome $F$ over the last Glacial cycle.

Further information can be obtained by contacting:

Pr. Okitsugu Watanabe

Dome F Ice Core Research Group, National Institute of Polar Research,

Kaga 1-910, Itabashi-ku, Tokyo 173, Japan

e-mail: glacier@nipr.ac.jp
Goddard, L. \& N.E. Graham 1997. El Niño in the 1990's. Journal of Geophysical Research, 102 10423 - 10436.

Latif, M., R. Kleeman \& C. Eckert 1997. Greenhouse warming, decadal variability or El Niño? An Journal of Climate, 10, 2221-2239.

Mann, M.E. \& J. Park 1994. Global-scale modes of surface temperature variability on interannual \& century timescales. Journal of Geophysical Research, 99, 25819-25833.

Rajagopalan, B., U. Lall \& M.A. Cane 1997. Anomalous ENSO occurrences: an alternative view. Journal of Climate, 10, 2351-2357.

Ropelewski, C.F. \& B.D. Jones 1987. An extension of the Tahiti-Darwin Southern Oscillation Index. Monthly Weather Review, 115, 2161-2165.

Trenberth, K.E. 1997. The definition of El Niño. Bulletin of the American Meteorological Society, 78, 2771-2777.

Trenberth, K.E. \& T.J. Hoar 1996. The 1990-1995 El Niño-Southern Oscillation Event: Longest on Record. Geophysical Research Letters, 23, 57. 60.

Trenberth, K.E. \& T.J. Hoar 1997. El Niño and climate change. Geophysical Research Letters, 24, 3057-3060.

Zhang, Y., J.M. Wallace \& D.S. Baltisti 1997. ENSOlike interdecadal variability: 1990-93. Journal of Climate, 10, 1040-1020. attempt to understand the anomalous 1990s 


\section{Five-year African lake study program funded by NSF}

U.S. university undergraduate students and young African researchers will study tropical lake science in a summer program based in Tanzania, on the shores of Lake Tanganyika, for the next five years. Lake Tanganyika is one of the great East African rift lakes, some of the most scientifically important and fast-changing tropical lake systems in the world.

The unique program, called the Nyanza Project, will be directed by Andrew S. Cohen, Professor of Geosciences at The University of Arizona in Tucson. The National Science Foundation (NSF) recently awarded Cohen a $\$ 780,000$ grant to develop an NSF Research Experience for Undergraduates (REU) program based at Tanzania Fisheries Research Institute facilities at Kigoma, Tanzania.

Students will be paid for all expenses and receive stipends to work with a multinational team of instructors who have a broad range of biological, geological and limnological research experience at Lake Tanganyika and its related lakes. Their course will consist of about three weeks of intensive laboratory and classroom training, followed by three weeks of independent research supervised by the faculty.

At the same time, Cohen and program faculty will run an identical course for young African scientists with funding and research support from the United Nations Global Environmental Facility (GEF).

The joint Nyanza Project fulfills part of the training mission of the International Decade of East African Lakes (IDEAL), a 5-year-old research and training consortium of African, North American and European scientists interested in all aspects of African lake science. Originally, the goal of IDEAL was to expedite a scientific program of coring the African lakes for their unique 10-million-year environmen- tal record. But the consortium has expanded its focus greatly because of rapid environmental change, especially at Lake Victoria, the largest of these lakes. Scientists are trying to understand the degree to which human impact and climate are causing rapid ecosystem changes.

For further information please contact:

for U.S. student inquiries

The Nyanza Project

Department of Geosciences

University of Arizona

Tucson, AZ 85721, USA

Tel: (520) 626-7312

Fax: (520) 621-2671

e-mail: nyanza@geo.arizona.edu

for African student inquiries

Lake Tanganyika Biodiversity Project

P.O. Box 90

Kigoma, Tanzania

Tel: 255-695-2992

Fax: 255-695-2992

e-mail: Itbp@łwiga.com

or visit LTBP's Web Site at:

http://www.nri.org/Lake_Tanganyika/homepage.html

\section{EAST AFRICA}

\section{A proposal to establish a new reference data set of climate-proxy indicators in East African lakes}

The lithology of a continuous 8.20-meter long sediment profile from Crescent Island Crater in Lake Naivasha (Kenya) has produced some of the strongest evidence yet for major climatic variability in equatorial East Africa over the past 1000 years. The magnitude of reconstructed lake-level fluctuations imply that the region was much wetter than today from the mid-1600s to the mid-1700s, and that severe drought occurred during the 'Medieval Warm Period' (about AD 1000-1250), the late 1500s, and the early 1800s. The more recent of these climatic anomalies were contemporaneous with highand lowstands of Lake Malawi and Lake Chilwa in southeast Africa that have been estimated to represent episodes when rainfall was as much as $40 \%$ higher or $70 \%$ lower than today, i.e. well beyond the long-term rainfall variability recorded in historical times. The continuity and excellent time resolution of the Crescent Island Crater record places these climatic anomalies in a chronological context that demands appreciation for the basic unpredictability of East Africa's landscape resources at the scale of human generations.

A collaborative effort by the University of Minnesota (USA), the University of Gent (Belgium), and Queen's University (Canada) now aims to complement and further constrain the late-Holocene lake-level record of Crescent Island Crater with a reconstruction of past salinity fluctuations based on the composition of fossil diatom and chironomid assemblages. The diatom-based, quantitative paleosalinity inferences will be able to make use of known salinity optima and tolerances of diatom species derived from a reference data set of diatom floras in 164 African lakes established by Françoise Gasse and coworkers, but a comparable reference data set of chironomid faunas does not currently exist. With recent progress into the taxonomy and ecology of larval Chironomidae in African lakes increasingly revealing the potential of chironomid-based quantitative paleosalinity reconstruction in semi-arid East Africa, the author now proposes to start an extensive field survey of lakes in Kenya, Uganda, Ethiopia, and Tanzania with the purpose of collecting chironomid and water chemistry data spanning the full gradient of aquatic environments from dilute mountain tarns to hypersaline playa lakes. In consideration of the logistic effort involved (helicopters are not likely to be a regular option), it appears appropriate that a field-survey protocol be established that maximizes the usefulness of collected samples and data to the wider paleoenvironmental research community. The author therefore takes the opportunity of this announcement to invite collaboration and ideas from researchers who would like to take advantage of the proposed large-scale lake survey to collect data that may promote the interpretation (or allow calibration) of other biological and geochemical climate-proxy indicators. This research effort will take 3-4 years to complete; funding has been obtained for a first field campaign planned for the Summer or Fall of 1998

\section{Dirk Verschuren}

Department of Morphology, Systematics, and Ecology University of Gent, B-9000 Gent, Belgium e-mail: dirk.verschuren@rug.ac.be
A French version of the PANASH-PEP III report has been produced by the CST (Centre des Sciences de la Terre) in Lyon (France). Entitled 'Paléoclimats des hémisphères Nord et Sud, le projet PANASH, les transversales Pôle-Equateur-Pôle' (Docum. Lab. Geol. Lyon, n 146, 1997), this document is available from the PAGES office in Bern. e-mail: pages@pages.unibe.ch 


\section{1st LBA Science Steering Committee meeting (Large scale Biosphere-Atmosphere experiment in Amazonia}

SAO Jose dos CAMpos, MARCH 31 st -APRIL 2ND 1997

The key questions for LBA are:

- How does Amazonia currently function as a regional entity?

- How will changes in land use and climate affect the biological, chemical and physical functions of Amazonia, including the sustainability of development in the region and the influence of Amazonia on global climate?

The LBA is divided in six general areas:- Physical Climate (which currently included the paleoclimate studies);

- Carbon Storage and Exchange;

- Biogeochemistry;

- Atmospheric Chemistry;

- Land Surface Hydrology and Water Chemistry;

- Land Use and Land Cover.

The LBA has been endorsed by IGBP as the first Integrated Global Change Science Project. Paleoclimate and paleo-environment studies are definitively included in the LBA frame, linked questions are described in the LBA Integrated Science Plan, soon to be published:

1. What have been the patterns of climate change (precipitation and temperature) on millennial to century time-scales in the Amazon environment?

2. How will analogues of past conditions, which generally represent an average of climate during several decades, help to improve our understanding of large scale mechanisms? (e.g. similarities have been observed between some climate variations during the last 7,000 years and present-day El Nino events).

3 . What is the relative importance of external forcing (e.g. changes in insolation, atmospheric $\mathrm{CO}_{2}, \mathrm{SST}$ ) vs internal mechanisms for Amazon paleo-situations?

4. What have been the impacts of extreme climate variations during the last millenia on Amazon environments (vegetation changes, fires, erosion).

A previous document (LBA scientific meeting) gave emphasis to lacustrine studies and sedimentological/palynological proxies. The new text also includes other methodologies such as: physical geography, fluvial geomorphology, biogeography of vertebrates, soils and soil organic content $\left({ }^{13} \mathrm{C},{ }^{14} \mathrm{C}\right.$, charcoal). Other South American records, including volcanic activity and Andean ice cap cores, must also be considered in our analysis. In fact, any contribution toward these objectives and the overall objectives of LBA are relevant. For example, the discussions on paleo-studies during the SSC also focused on other contributions: - high resolution sonic profiles $(3.5 \mathrm{kHz})$, which appear necessary for the study sites in alluvial plain;

- methods for providing a record of past seasonallity (speleothems, tree rings, laminated lacustrine sediment).

Operations and funding are now better defined:

- a US contribution from NASA, mainly dedicated to atmospheric studies, but also considering ecological research (a research announcement has been made) and hydrology / biogeochemistry.

- an EU contribution, to be defined during a European LBA-Worshop, in June-July. This last one, included in the G7 Pilot Project, is dedicated only to Brazil.

- a Brazilian consortium, to be created, including three agencies (FINEP, FAPESP, CNPQ) - other contributions are from IAI and some European projects.

From an operational point of view, the European funding is, for the moment, restricted to Brazilian sites. For paleo-studies it may offer opportunities for European research in cooperation with Brazilian Institution, but many important EU contributions in other Amazonian countries have to be included in further projects. At the moment, specific research projects linked to the German Program SHIFT or to the French Program, from ORSTOM, AIMPACT, are capable of contributing to integration of the European LBA.

Many objectives of LBA paleo-studies cannot be restricted to Brazil or US or EU operations. One of the most important is the creation of a data bank of present-day pollen deposition, which is also an objective of the PAGES and GCTE Core Projects of IGBP. Such an objective requires full participation by all Amazonian palynologists, in conjunction with Botanists, Climatologists and Statisticians. An effort must then be made, by the scientific community, for the integration of research funded by different countries (Brazil, USA, EU).

The sites for paleo-environment and paleo-climate studies should be, if possible, close to the LBA study sites (where all other researches are centered). The sites chosen dur-

\section{Spatial-Temporal Dimensions of High-Latitude Ecosystem Changes}

\author{
Krasnoyarsk, Russia, September 2-7, 1997
}

The Institute of Forestry, Krasnoyarsk, recently hosted a workshop on "SpatialTemporal Dimensions of High-Latitude Ecosystem Changes" as a contribution to the development of the IGBP North Siberian Transect. PAGES was represented by expertise in dendro-climatology (notably Keith Briffa, University of East Anglia and Malcolm Hughes, University of Arizona, in addition to members of the Forestry Institute under Eugene Vaganov's leadership) and in peat and sediment studies. The programme included an excursion to contrasted forest sites in the region and a wide range of scientific presentations and discussions. Recognition of the vital role of 'dendro-research' in establishing fire histories, the nature of disturbance regimes and forest stand dynamics at the patch scale, as well as in providing high resolution paleoclimatic information and estimates of changing (continued top of next page)

ing this SSC meeting were Rondonia, Sao Gabriel da Cachoeira, Tefe (Mamiraua), Manaus, Santarem, Maraba and Brasilia, this last one representing the extraAmazonia reference site.

For neighbouring countries, some sites have been cited:

- Noel Kempf Reserve (NE Bolivia),

- Sao Carlos do Rio Negro (Venezuela),

- Puerto Maldonado (Peru),

- Napo Valley (Equador),

- Leticia and Araracuara (Colombia).

In the physical climate realm, comparisons may be made on a larger space scale, Amazonia climate variations should be compared with extra-tropical records.

My final consideration would be that a clear call has been made by the LBA, to the paleo-community. This is an excellent opportunity to demonstrate the utility of paleoenvironmental reconstructions for a better understanding of the current and future behavior of environmental systems. This regional approach provides a favourable opportunity to put different fields of science in contact with each other.

\section{Bruno Turce \\ ORSTOM-UFF \\ Departamento de Geoquimica \\ Morro do Valonguinho s/n, 24020-007 \\ Niteroi, Brazil \\ e-mail: Geoturc@vm.uff.br}


biomass, was one of the clear highlights of the meeting. Carbon sequestration in boreal ecosystems was a major linking theme of the workshop and the complementary roles of forest, soil and peat studies were emphasized. The potential role of peat, hydromorphic soil and lake sediment studies in reconstructing not only past vegetation and forest dynamics but also mineral flux, within defined watershed-ecosystems, was accepted as a component of the implementation plan for the transect. The environmental context provided by the North Siberian transect is rich in paleoarchives and is one where there is every opportunity for PAGES science to interact with other parts of IGBP, notably GCTE and BAHC.

The meeting also gave an opportunity for the assembled scientists to celebrate the honour recently achieved by one of the retiring PAGES Scientific Steering Committee members, and Director of the Institute of Forestry, Dr. Eugene Vaganov, namely his election as an Academician.

\section{Frank Oldfield}

Executive Director

PAGES IPO

e-mail: frank.oldfield@pages.unibe.ch

\section{C-T. A. Chen and T. Hama awarded Biwako Prize}

The Biwako Prize for Ecology was founded by the Shiga Prefectural Government of Japan in 1991 in the hope of contributing to the progress of aquatic environment studies in the fields of limnology, oceanography, ecology and related sciences. Biwako means 'Lake Biwa', the largest lake in Japan and the third oldest in the world. Each year a certificate of merit and five million Japanese yen (about \$ 40,000 US) are awarded to two researchers chosen by the Shiga Prefectural Government and the International Lake Environment Committee. This year recipients were Dr. ChenTung Arthur Chen of the Institute of Marine Geology and Chemistry, National Sun Yat-sen University, Taiwan and Dr. Takeo Hama of Nagoya University, Japan.

Dr Chen was noted for his research related to the oceanic $\mathrm{CO}_{2}$ problem and PAGES related work in the lacustrine environment in Taiwan. Dr. Hama was noted for his research on primary productivity in the oceans.

\section{Land Use and Land Cover Change (LUCC) / IGBP-DIS Data Requirements Workshop}

Barcelona, Spain, November 11-14, 1997

PAGES presentations were made by Suzanne Leroy and Frank Oldfield

The importance of studying long term records of land-use/land-cover (LU-LC) change was acknowledged at the meeting. One goal shared by LUCC and PAGES will be to document, by all available means, the history of LU-LC change over the last 200 years. This is in accordance with the views expressed more widely at the IGBP Congress in 1996. The spatial cover will ideally be global, though regional disparities in data are recognised as a significant limitation for some parts of the world. In order to achieve this initial goal, it will be necessary to generate a common commitment between interested groups in LUCC and PAGES, which, in turn, implies developing the initiative in ways that can generate mutual benefits to both communities.

As a first step, it was proposed to hold a small workshop (10-12 people) with, as its proposed title:

"Historical Dynamics of Land Use, AD 1800 to $1997^{\prime \prime}$

The main aims of this would be to:

- define and start to establish a collaborative community willing and able to carry the initiative forward;

- address, as required, the question of data calibration with respect to fully documented LU-LC categories at the present day and in the recent past;

- define and promote rationales for the initiative that would attract broad support and participation;

- create classification schemes directly linked to LUCC activities and priorities;

- resolve issues of spatial scale and temporal resolution;

- establish guidelines for regional and methodological contributions and for harmonising these to create a global data set; - identify and build on existing data sets.

The likely participants in such an initiative are quite diverse, as are the types of data they use and the insights they can provide. They include, for example, pollen analysts, historical geographers, environmental historians, dendro-ecologists and landscape ecologists. Harmonising the interests, skills and data output of such a disparate group is a non-trivial task.

The most practical product of the initiative would be a spatially referenced data base from which a series of time-slice maps, for example, could be generated at any stage and refined as the project progressed.

It was suggested that DIS, LUCC, PAGES, GAIM and GCTE were all potential participants from within IGBP.

Any members of the PAGES community who are interested in taking part in such an initiative should contact the Project Office.

Other PAGES-related themes that were considered included:

- the need for longer term perspectives, especially in ecosystems like forests, where successional/competitive processes took place over longer periods of time. In such cases, biophysical feedbacks, species composition and ecosystem structure and function may change on relatively long time scales and a perspective from 200 to 1000 years was considered desirable;

- the importance of studies documenting nonreversible human impact on fragile ecosystems in the past;

- the need to include a well articulated historical dimension in regional case studies of special significance to LUCC;

- the value of exploring the impact of natural climate variability on LU-LC.

\section{Frank Oldfield}

Executive Director

PAGES IPO

e-mail: frank.oldfield@pages.unibe.ch

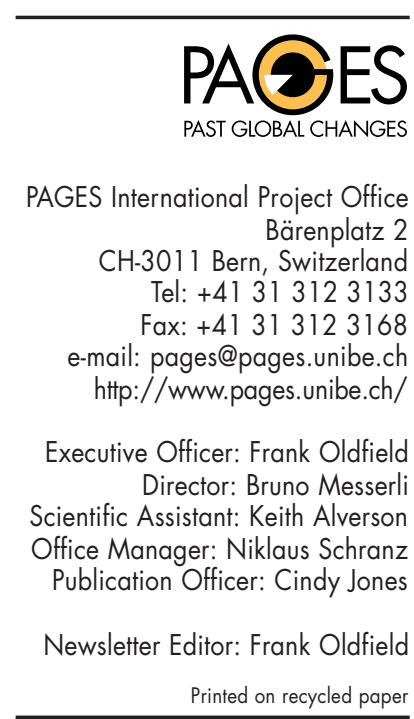




\section{Activities of PAGES Lake Drilling Task Force}

\section{Origin of the Lake Drilling Task Force}

Because successful acquisition of long continental paleoclimate records requires major investments in planning, logistics, and drilling technology, it is important to select the most promising sites, to conduct pre-drilling site evaluations, and to select the most suitable drilling technology. To facilitate a coordinated selection process, participants at the PAGES Workshop on Continental Drilling for Paleoclimate Records (see PAGES Workshop Report Series 96-4, WWW address below) agreed to form a Task Force to organize a coordinated Global Change initiative for national and international funding agencies. A particular target for engagement was the then-emerging International Continental Scientific Drilling Program (ICDP). The goal of the Lake Drilling Task Force is to provide some coordination for the notoriously fragmented continental paleoclimate community, and to facilitate large-scale international efforts to retrieve long (ca. $250 \mathrm{kyr}$ ) lacustrine records analogous to those generated by the marine and ice-core communities. The Task Force promotes the development of a regional network of long, continental paleoclimate records, closely associated with the Time Stream II activities and priorities of the PEP transects. With respect to ICDP, we hope to form partnerships between ICDP, which would support drilling operations and technology, and national or international science funding agencies, which would provide support for scientists and analytical work.

Individuals serving on the Task Force are the leaders of PEP I (V. Markgraf), PEP II (J. Dodson and Liu Tungsheng), and PEP III (F. Gasse), along with several people associated with large lake coring or drilling projects and related activities (D. Williams, T. Johnson, J. Negendank, S. Leroy, and S. Colman). Doug Williams served as head of the Task Force through November, 1996; Steve Colman now serves in this capacity.

\section{ICDP}

The International Continental Scientific Drilling Program (ICDP) grew out of the need for a continental version of the Ocean Drilling Program. Its origins lie largely in the deep crustal drilling community, especially the U.S. Continental Scientific Drilling Program and the German KTB Drilling Program. ICDP was formally launched by a memorandum of understanding between the U.S. and Germany in 1996. It operates on funds contributed by membership fees, on a sliding scale, decreasing from the current fee of 700,000 US\$ for G7 countries. Initial members were the U.S., Germany, and China. Countries likely in the near future include Japan, Mexico, Russia, a consortium of small European countries, and UNESCO (for developing countries). The organization is run by an Executive Committee consisting of one representative from each member country. Proposals are reviewed by a Science Advisory Group, which makes funding recommendations to the Executive Committee.

\section{History}

Under the leadership of Doug Williams, the Task Force solicited from the continental paleoclimate community two-page proposals for lakes that should be considered and prioritized for drilling support by ICDP. The proposals included a brief description of the lake(s) of choice; the rationale for selection in terms of scientific questions to be addressed, prospects for success, and logistical challenges anticipated; a list of participating scientists, and an estimated budget. More than 60 of these mini-proposals were submitted to the Task Force and were reviewed at a meeting of the Task Force in October, 1995.

The Task Force evaluated the proposals primarily on the basis of the likely quality of the paleoclimate records to be obtained, the scientific importance of records from particular sites, and the relation of particular sites to the goals of the PEP transects. To some degree, the readiness of proposed projects affected the order of priority among the highest rated proposals. More complete proposals were requested for lake sites evaluated as having the highest priority by the Task Force. These materials were compiled into a five-year drilling plan, which was presented to ICDP at the VIII International Continental Drilling Symposium in February, 1996, in Tsukuba, Japan. The plan was also circulated to the international community for additional input. In response to ICDP's initial call for pre-proposals, the plan was submitted to ICDP in April, 1996, as a "Prospectus for a Global Lake Drilling Initiative." At the same time, individual proposals were submitted by the leaders of six lake drilling projects, five of which were among those evaluated by the Task Force and included in the Prospectus.

The Task Force Prospectus proved difficult for ICDP to handle, so ICDP did not consider the Prospectus nor the included projects in its review of original pre-proposals. In order to resolve this problem and other concerns related to PAGES projects, including length of record and the inclusion of tectonic studies, ICDP funded a workshop, which was held at Lamont-Doherty Earth Observatory in December, 1996, attended by all of the PAGES Task Force members. Information concerning this Workshop, including a draft report, is available on the World Wide Web (address below). The meeting resulted in a clearer understanding of the priorities of ICDP and a greater appreciation for the importance of lacustrine paleoclimate records.

One of recommendations of the Lamont workshop was that a PAGES representative be appointed to the Science Advisory Group of ICDP, the group that reviews proposals. Steve Colman was asked to fill this role and joined the SAG for its yearly review of proposals (submission deadline 15 January). Remarkably, eight proposals related to paleoclimate records from lakes were submitted to ICDP, representing almost half of all drilling proposals. Out of the proposal process, the Baikal Drilling Project received substantial funding for core-logging equipment, the Lake Titicaca and IDEAL projects received limited funding for workshops and (or) engineering studies, and a planning workshop was recommended for the Qinghai Lake (China) project. Some problems, such as participation in ICDP by small developed countries (e.g. New Zealand) remain, but are being addressed.

\section{Recent developments}

In response to the many high-quality lakedrilling proposals, particularly the favorable reviews of the East African lakes (IDEAL) and Lake Titicaca proposals, ICDP is proceeding with development of technical and engineering capabilities for drilling medium to large lakes. They supported a small workshop in Miami in October, 1997, organized by Chris Scholz, which included engineers from ODP and industry (WWW information below). This faceto-face discussion between scientists and engineers was extremely productive and resulted in a recommendation for a formal feasibility study of the costs and performance of different systems for drilling the lakes in question. ICDP agreed to fund the study, and the request for proposals has been issued. The award is expected to be made in December, 1997 and the results are expected in March, 1998. We are now confident that one of these lakes, probably Lake Edward, will be drilled in the near future, possibly as early as 1999 .

The next round of proposals for ICDP is due January 15, 1998. In the meantime, the Lakes Drilling Task Force will continue to seek ways to promote the drilling of lakes for paleoclimate records in general, as well as providing an interface to ICDP.

(continued on page $9 \mathrm{col}$. 1, bottom) 


\section{The Center for Field Research invites proposals for 1998-1999}

The Center for Field Research invites proposals for 1998-99 field grants funded by its affiliate Earthwatch.

Earthwatch is an international, non-profit organization dedicated to sponsoring field research and promoting public education in the sciences and humanities. Past projects have been successfully fielded in, but are not limited to the following disciplines: aquaculture, limnology, marine resource conservation, oceanography (chemical, biological and physical) and marine geology. Interdisciplinary projects are especially encouraged as is multi-national collaboration.

Information can be found at:

The Center for Field Research,

680 Mt. Auburn St., Watertown, MA 02272, USA:

Tel: (617) 926-8200; Fax:(617) 926-8532;

e-mail:cfr@earthwatch.org

http://www.earthwatch.org/cfr/cfr.html

\section{PAGES CALENDAR}

(*: Open meetings. All interested scientists are invited to attend)

*February 9-2, 1998, Boulder, CO, USA "Second Workshop on Global Paleoenvironmental Data"

Contact: Robin Webb or Dave Anderson. Tel: +1 303497 6160; Fax: +1 303 497 6513; e-mail: danderson@ngdc.noaa.gov, rwebb@ngdc.noaa.gov

*February 16-20, 1998, Chiang Mai, Thailand "Southeast Asian Dendrochronology Workshop" (SEA Dendro' 98)

Contact: Rosanne D'Arrigo, Tree-ring lab., Lamont-Doherty Earth Observatory, Palisades, USA. Tel: + 9143658617 ; Fax: + 9143658152 ;

http://www.ldeo.columbia.edu/trl/seal.html\#SEA.Dendro98

*March 14-18, 1998, Barcelona, Spain "GCTE-LUCC Science Conference (Global Change in Terrestrial Ecosystems-Land Use/Cover Change)"

Contact:Will Steffen, GCTE Core Project Office, CSIRO Division of Wildlife \& Ecology, PO Box 84, Lyneham, ACT 2602, Australia. Fax: +61 12412362 , e-mail: wls@cbr.dwe.csiro.au; http://jasper.stanford.edu/CGTE/LUCC/ conference98.html

"March 16-20, 1998, Merida, Venezuela "PEP 1 Meeting" Contact: Dr. Vera Markgraf, INSTAAR, University of Colorado, Boulder CO 80309 0450, USA. e-mail markgraf@spot.colorado.edu; http://instaar.colorado.edu/misc/pep.html

*April 19-23, 1998, London, UK "First PAGES Open Science Meeting", ***New Location*** Senate House, University of London, UK Contact: Frank Oldfield, PAGES IPO, Switzerland. Tel: +4131312 3133; Fax: +41313123168; e-mail: pages@pages.unibe.ch; http://www.pages.unibe.ch/osm/newosm.html

${ }^{*}$ May 18-21, 1998, Yarmouk University, Irbid, Jordan "Learning from the Past: Global Paleoclimatic Changes"

Contact: Prof. Ali Jawad Ali, Faculty of Science, Yarmouk University, IRBID, Jordan. Tel: +962 2271100; Fax: +962 2247983/274725; e-mail: ajawad@yucc.yu.edu.jo

*May 16-23, 1998, Torshavn, Faroe Islands "Environmental Change in Atlantic Islands"

Contact: C. Caseldine, University of Exeter, UK. Tel: +44 1392263347

Fax: +44 1392263 342; e-mail: c.j.caseldine@exeter.ac.uk

*June 14-18, 1998, Snowbird, Utah, USA "Chapman Conference on Mechanisms of Millennial-Scale Global Climate Change"
Contact: AGU Meetings Department, Millennial-Scale Global Climate Conference, 2000 Florida Av, N.W., Washington, D.C. 20009, USA. Tel: +1 202462 6900; Fax: +1 202328 0566; e-mail: meetinginfo@kosmos.agu.org

* July 2-7, 1998, Perth, Australia - PEP-II Workshop in "Variability of Southern Hemisphere Climate Systems and Linkages with Northern Hemisphere Systems, on Time Scales covering the last two Glacial

Cycles" - University of Notre Dame, Fremantle

Contact: John Dodson. e-mail: johnd@sunny.gis.uwa.edu.au

*July 6-10, 1998, Exeter, UK "Hydrology in a Changing Environment"

Contact: Dr Bruce Webb, Department of Geography, University of Exeter, Armory Building, Rennes Drive, Exeter, Devon, EX4 4RJ, UK. Fax: +44 1392 263342; e-mail: b.w.webb@exeter.ac.uk;

http://wlfiles2.nwl.ac.uk/ih/prototype/new/bhs.html

*July 27-August 7, 1998, Lanzhou, P.R. China, International Symposium and Field Workshop on "Paleosols and Climatic Change"

Contact: Pr Fang Xiaomin, Lanzhou Univeristy, Lanzhou, Gansu Province 730000 P.R. China. e-mail: fangxm@|zu.edu.cn

*August 23-28, 1998, Lisbon, Portugal "International Conference on Paleoceanography - ICP VI"

Contact: F. Abrantes. e-mail: icp6fatima@mail.telepac.pt

*September 5-7, 1998, Puerto Vallarta, Mexico - 15th AMQUA Biennal Meeting on "Northern Hemispheric-Southern Hemispheric Interconnections"

Contact: Dra. Socorro Lozano Garcia. e-mail: amquamex@servidor.unam.mx Fax: +52 5550 6644; http://www.usu.edu/ amqua/v27nl/meeting.html * September 7-1 1, 1998, University of East Anglia, Norwich, UK "Climate and History: Past and Present Variability - A Context for the Future"

Contact: Susan Boland, Climatic Research Unit, University of East Anglia Norwich, NRA 7TJ. Tel: +44 1603 456161; Fax: +44 1603 507784; e-mail: s.boland@uea.ac.uk; http://www.cru.vea.ac.uk/cru/conf/

*August 3-11, 1999, Durban, South Africa "The Environmental Background to Hominid Evolution in Africa", INQUA XV International Congress, International Congress Centre Durban

Contact: Dr D.M. Avery, Secretariat General, South African Museum, P.O. Box 61, Cape Town 8000, South Africa. Tel: +27 21 243330; Fax: +27 2124671 ; e-mail: mavery@samuseum.ac.za; http://INQUA.geoscience.org.za/ (continued from page 8)

\section{Additional information (WWW)}

- ICDP and proposals:

http:/ / www.gfz-potsdam.de/icdp

- Lamont ICDP Workshop:

http: / / www.ldeo.columbia.edu/ polsen/

nbcp/lake.html (including draft report)

- Miami ICDP Workshop:

http:/ / www.gfz-potsdam.de/icdp/miami - PAGES Task Force:

http:/ / woodshole.er.usgs.gov/ scolman/ pages/ldtf.html (includes links to other related items)

- PAGES Workshop Report 96-4:

http:/ / www.pages.unibe.ch/Publications / Workshops/Contidrill/Otoc.html

\section{INSIDE PAGES}

\section{Changes at the PAGES IPO}

1997 has been a year of considerable change at the PAGES IPO. Ulrich Schotterer has concluded his role as PAGES scientific assistant. As well as continuing to work towards the enhancement of the Global Network for Isotopes in Precipitation, he will also concentrate his efforts on a new, independent, scientific initiative on Isotopes in the Hydrological Cycle (ISOHYC).

In his place, PAGES welcomes Keith Alverson, a physical oceanographer with interests in oceanic convection, air-sea interaction, and the application of inverse modelling techniques to paleoclimate model-data comparison problems.

Finally, PAGES has benefited enormously from the hiring of Niklaus Schranz as office manager. Niklaus has a background in geography and brings strong electronic communications skills to the office. 


\section{PEP 1 Paleoclimates of the Americas}

\author{
Merida, Venezuela, March 16-20, 1998
}

To further our understanding of interhemispheric climate linkages in the Americas, present and past, a meeting is convened in Merida, Venezuela, March 16 to 20, 1998. The meeting represents the first attempt to address the goals defined by the IGBP-PAGES initiative "Pole-Equator-Pole Paleoclimates of the Americas" (PEP 1).
These goals are:

1) to document the inter-relation between climate change patterns in the Americas in terms of amplitude, phase, and geographic extent; and

2) to determine the forcing factors which affected each hemisphere's as well as the interhemispheric climate change patterns.
Sixty-two speakers have accepted the invitation to present an inter-hemispheric overview of climate change and climate variability from instrumental climate, terrestrial, ice core and marine records in the Americas, for specific time intervals, present and past.

In addition, 28 posters have been submitted for the poster session, representing specific the sessions' topics.

From the meeting a book will be produced, containing chapters on the session's topics.

\section{PEP 1 Meeting Agenda}

\section{Modern Climate Variability}

Henry Diaz, coordinator

- Miguel Acevedo, Rigoberto Andressen, Kent MCGregor,

Hirma Ramirez and Magdiel Ablan: Climate Variability Scenarios for the Llanos of Venezuela: Soil Moisture and SST anomalies

- Mike Dettinger and Dan Cayan: Historical Modes of Interannual and

Decadal Hydroclimatic-Hydrologic variability in the Western Hemisphere

- Dave Enfield: Western Hemisphere Modes of Ocean-Atmospheric

Co-Variability

- Stefan Hastenrath: Atmospheric Circulation of the Tropical Americas

- Jose Marengo: Cold Front and Polar Advections in the Americas during Modern and Past Climates

\section{Last 2000 Years Climate Variability}

Malcolm Hughes, Tim Baumgartner and Lonnie Thompson, coordinators

- Jose Boninsegna and Malcolm Hughes: Tree Ring Records from the Americas

- Tim Baumgartner and Marco Salamanca: Developing a Paleoclimate Transect for Marine Sites along the Eastern Pacific Margin

- Tim Baumgartner, Andy Soutar and F. Ferreira: Patterns of Interhemispheric Climate Change of the Past 2000 Years Inferred from high-Resolution Marine Sediment Records of the Eastern Pacific - Thomas Kitzberger, Thomas Swetnam and Thomas Veblen:

A Comparison of Fire Histories and Climatic Change in the Southwestern United States, and Northern Patagonia, Argentina

- Brian Luckman: Assessing Synchroneity of Glacier Fluctuations in the Western Cordillera of the Americas during the Last Millennium

- Lonnie Thompson: Climate of the Last 2000 Years in the Tropical Andes of South America

- Sheri Fritz: Moisture Patterns in the Americas over the Last 2 Millennia Inferred from Lacustrine Records

\section{ENSO Cumate Variability}

Robert Dunbar, coordinator

- Dave Battisti: Climate Phenomenon on Interannual to Decadal time scales that have Interhemispheric Impacts on the Americas

- Julie Cole and Ed Cook: Changing Relationship between ENSO and

North American Drought

- Alexey Kapan: Globality and optimality in climate fields

reconstructions: ENSO and more

- Luc Ortlieb: Historical Records of ENSO

- Ricardo Villalba, Rosanne D'Arrigo, Ed R. Cook, G. Wiles and

G. Jacoby: Decadal-scale Climatic Variability along the Extra-tropical

Western Coast of the Americas over Past Centuries inferred from Tree-ring

Records

- Rosanne D'Arrigo and D.W. Stahle: Multiproxy Reconstructions of the Southern Oscillation

\section{Human Dimensions}

Diana Liverman, coordinator

- Diana Liverman: The Human Dimensions of Global Change in the Americas: An Overview

- Mark Brenner, Hodell, D.A., Leyden, B., Curtis, J.H., Binford, M.W., Kolata, A.L. and Abbott, M.B.: Environmental Determinism Revisited: Climatic Limits on Cultural Development
- Lautaro Nunez: Eventos de Aridez Pleistoceno-Holocenicos en el Centro-Norte de Chile y su Correlacion con los Primeros Poblamientos del Cono Sur

- Roberto Sanchez: Vulnerability of Latin American Cities to Climate Change and Climate Variability

- Payson Sheets: The Effects of Explosive Volcanic Eruptions on Simple-to-

Complex Societies in Ancient Middle America

Mid-Holocene Climate Variability

Julio Betancourt, Wolfgang Volkheimer, coordinators

- Walter Dean, Sarah Metcalf, Philippe Mourguiart: Lacustrine Records of Mid-Holocene Climates of North America

- Eric Grimm and Socorro Lozano-Garcia: Vegetational Signal in the Americas of Geographically Variable Climate Forcings during the Mid Holocene

- Dan Muhs: Late Quaternary Eolian Records in North America with a Comparison to Eolian Records in South America;

- Marcelo Zarate: Late Pleistocene and Holocene Eolian Records of

Southern South America (The Pampas and the Chaco Region)

- Jan Heine: Mid-Holocene Glacier Advances in North America;

- Geoff Seltzer:Holocene Glaciation in Central and South America

late Glacial Climate Variability

Henry Hooghiemstra, Vera Markgraf, Cathy Whitlock, coordinators

- Platt Bradbury: Late-Glacial (15 - 8 ka) Lake Records along PEP 1 Transect: Their Role in Developing Inter-hemispheric Paleoclimate Interactions;

- Martin Grosjean: Late Glacial and Holocene Climate Changes on the

Southern Altiplano (20-28S)

- Marie Pierre Ledru and Maria Lea Salgado-Labouriau: Vegetation

Records in North and South America

- Scott Lehman and Carlos Herguera: Marine Records

- Dorothy Peteet: Late-Glacial Climate Variability - GCM Modeling

Experiments

- Geoff Seltzer: Late Glacial Glaciaton in Central and South America;

Jan Heine: Late-Glacial Glaicer advances in North America

- Jim White: Polar lce Core Records

- J.M. Pajon and F. Ortega: Paleoclimatic and Paleoenvironmental

Studies in Cuba

\section{Fullglacial Climates}

Thomas Pedersen, Miguel Angel Gonzalez, coordinators

- Allan Ashworth: A Comparison of the Beetle Faunas of the Last Glaciation from the Mid-latitudes of North and South America

- Chalmers Clapperton and Max Bezada: Full-Glacial Glacier Extent and Chronology along the PEP 1 (Americas) Transect

- Jim Kennett: Late Quaternary Climate and Ecosystem Instability: Southern California Margin

- M.A. Gonzalez: Lake Records of the Americas

- Todd Sowers: Interhemispheric Linkages during the Last Glacial period

- Robin Webb: High versus Low Latitude Glacial Climate Sensitivity in the

Americas: Results from PMIP Simulations and Other Sensitivity

Experiments

- Cathy Whitlock: Features of the Full-Glacial Vegetation of the Americas

- Michel Servant: Comparison of Fullglacial Climatic Features in South

America and Africa 


\section{Chapman Conference on Mechanisms of Millennial-Scale Global Climate Change}

SNOWBIRD, UTAH, USA, JUNE 14-18, 1998

Cliff Lodge Snowbird Conference Center

\section{Conveners:}

Peter U. Clark, Department of Geosciences, Oregon State University, Corvallis, OR, USA

Robert S. Webb, NOAA-NGDC Paleoclimatology Program, Boulder, CO, USA

Program Committee:

Richard B. Alley, Antony J. Broccoli, Wallace S. Broecker, William Curry, Laurent Labeyrie and Alan Mix

\section{Conference Scope:}

This conference will provide an international forum for discussion of possible mechanisms that may account for millennialscale climate change. Unlike orbital-scale climate change, which has a well-defined forcing mechanism in changes in solar insolation, the cause(s) of millennial-scale climate variation remain(s) unknown. The growing global paleoclimate database relevant to this issue is now of significant breadth to provide the critical information required to address these issues.

The central themes of this conference will address two key questions that arise from evidence of millennial-scale climate change:
(1) What is the sensitivity of various components of the Earth's climate system to millennial-scale climate change?

(2) What are the mechanisms, linkages, and feedbacks which produce millennial-scale climate change?

A subset of these general themes includes: - Is millennial-scale climate change a characteristic only of ice-age boundary conditions, or do those conditions simply amplify an ongoing process?

- Is millennial-scale climate change globally synchronous?

- If so, is the change symmetrical (of equal sign) across both polar hemispheres?

- Are the linkages made through the atmosphere, the deep and surface ocean, or both?

- If globally synchronous, does millennialscale climate change represent an internal climate oscillator originating in the North Atlantic region and transmitted globally through the atmosphere and oceans?

- Does millennial-scale climate change represent a common global forcing mechanism transmitted from the tropics?

- Do changes in the southern hemisphere drive climate change elsewhere?

- What are the feedbacks between various components of the Earth's climate system at these timescales?

- Does all millennial-scale climate change share a common forcing (internal or external), or do several possible forcing mechanisms exist which independently produce millennial-scale climate change?

For further information please contact:

\section{AGU Meetings Department}

Millennial-Scale Global Climate Conference 2000

Florida Avenue, NW

Washington, DC 20009, USA

Tel: (202) 462-6900

Fax: (202) 328-0566

e-mail: meetinginfo@kosmos.agu.org

\section{NETHERLANDS FOUNDATION FOR SCIENTIFIC RESEARCH (NWO) FUNDS IMPLEMENTATION OF PAGES RESEARCH}

\section{Climatic change at low elevation: expedition to the savannas and rain forest of Colombia}

Paleoecological and paleoclimatological knowledge of northern South America is mainly based on Andean studies. Current key questions concern especially the lowlands. It is still not clear how much tropical lowlands cooled during the last glacial maximum (LGM) and to what degree changes in precipitation were relevant. The changes were possibly more than first CLIMAP estimates of $<2^{\circ} \mathrm{C}$, perhaps less than $8^{\circ} \mathrm{C}$ often claimed in palynological studies from the Colombian Andes. Recently, a cooling of Amazonan lowlands by $4^{\circ} \mathrm{C}$ for the LGM is claimed by both "schools" debating the Amazonian refuge theory. Also for paleodata-model comparisons reliable paleo-vegetation maps are missing.

The Netherlands Foundation for Scientific Research (NWO), Geological, Oceanographic and Atmospherical Research branch (GOA), funded the post-doc project «Paleo-ecology of 0-20 kyr tropical America based on new pollen records and integration of existing palynological data» for 3 years. A field expedition to the savannas of the Llanos Orientalis, and the rain forest of Choco was part of the project. We aimed to core the maximum number of lakes and swamps in order to give expensive expeditions the maximum scientific effect.

During January-February 1996 we visited with two 4-wheel-drive cars and our new Livingstone Corer (modified by Paul Colinvaux) the savannas of NE Colombia, mainly at 150-200 m altitude. Over a transect of $600 \mathrm{~km}$ we cored 12 lakes. Core length varied from $10 \mathrm{~m}$ close to the Eastern Cordillera to $1 \mathrm{~m}$ in the centre of the Llanos. First radiocarbon dates show most cores represent the last 8,000 to 12,000 years, one core reaches 18,000 years showing the savanna in the LGM.

In August 1996 we visited the interAndean valleys of the Rio Cauca and Rio Patia in southern Colombia. We cored 4 peat bogs at $1020 \mathrm{~m}$ altitude in the humid Cauca Valley. Cores were 2 to $7 \mathrm{~m}$ long and first radiocarbon dates show these records reach 8,000 to 13,000 years back in time. In the dry Patia Valley we cored 4 lakes at $760 \mathrm{~m}$ altitude. Cores were 3 to $5 \mathrm{~m}$ long and first radiocarbon dates show these records reach 6000 to 11,000 years back in time. During January-February 1997 we had our most difficult expedition to the Pacific rain forest of Choco. Travel, organisation and physical conditions were challenging. We cored a lake in each of the 3 provinces that constitute the "Choco biogeographic area". The 3 cores are 5 to $6 \mathrm{~m}$ in length. One core was raised with the Livingstone Corer from $23.5 \mathrm{~m}$ water depth. Perhaps these cores will help us to discover why the Choco rain forests have the largest biodiversity in the world.

Expertise at the Hugo de VriesLaboratory concerns pollen analysis and time control. But we would be delighted if other colleagues are interested to make use of our core material to study additional proxies, such as diatoms, phytoliths, geochemistry, etc. Especially colleagues in the PEP-1 community are invited to contact us to discuss proposals for joint studies.

Prof. Dr. Henry Hooghiemstra

Hugo de Vries-Laboratory

The Netherlands Centre for Geo-ecological Research (ICG)

University of Amsterdam

Kruislaan 318

1098 SM Amsterdam, The Netherlands

Tel: 31205257857

Fax 31205257662

e-mail: hooghiemstra@bio.uva.nl 


\section{Putting PAGES together}

For the first time since the establishment of its program of Foci and Activities, PAGES has held a meeting of virtually all the scientists responsible for coordinating PAGES research throughout the world. This Leaders Meeting took place in Hilterfingen, Switzerland on the north shore of Lake Thun, November 8 and 9, 1997. The main goals of the meeting were to summarize progress in each area of activity, to review the PAGES project as a whole, to promote synergism between the various research teams and to put PAGES on course for making the best possible impact at the Open Science Meeting.

PAGES derives its distinctive identity from prioritizing the study of those aspects of past global change that contribute crucially to our understanding of Earth system function on human timescales and to our capacity to improve the quality of any assessment of future climate changes and their impacts. Even with this strongly focused research agenda, the range of tasks to which PAGES is committed is broad and diverse. The challenge of synthesizing the results is a daunting one. Full documentation of all the PAGES activities will soon be available through publication of the 'PAGES Status Report and Implementation Plan', now complete and due for publication early in 1998.

To some degree, the structure of PAGES includes built-in patterns of coordination. Some of these, like PEP I, are already at the stage where preliminary syntheses can be attempted (see Calendar entry on the Merida Meeting). Beyond these, the PAGES Open Science Meeting to be held in London April 20 - 23, 1998, will provide an over-arching compilation of PAGES science and of its significance for the future (see this page).

In parallel with presentational syntheses at meetings and in the publications that grow out of them, PAGES shares an additional key responsibility: the WDC-A Paleoclimate Data Base which can be accessed via either NGDC in Boulder Colorado (http://www.ngdc.noaa .gov/paleo/igbp-dis/index.html) or MeteoFrance in Toulouse, France (http://www. cnrm.meteo.fr:8000/igbp) constitutes a major global resource and a long term PAGES legacy of growing value. Efforts are underway to ensure that the facility meets the data needs of all PAGES research. The Data Workshop in Boulder, (February 9 - 12, 1998) is an important stepping stone in this direction.

\section{Pages Open Science Meeting}

Senate House, University of London, April 20 - 23, 1998

Draft Program

Monday April. 20

$8.45-9.25$ Ray Bradley

$9.25-10.05$ Keith Briffa

$10.15 \cdot 10.45$ Mike Gagan Coffee break

$11.15-11.55$ Lonnie Thompson 11.55 - 12.35 Vera Markgraf

\section{Lunch}

14.00 - 14.40 Zhisheng An

14.40 - 15.20 Françoise Gasse

15.20 - $16.00 \mathrm{Jim}$ Knox

$16.00 \cdot 18.00$ Poster session

\section{Introductory overview}

Annual climate variability in the Holocene; interpreting the message of ancient trees.

Corals: grand archives of tropical paleoclimate

Ice core evidence for climate change in the Tropics: Implications for our future Interhemispheric paleoclimate linkages and forcing in the Americas from decadal to millennial scales

The history and variability of East Asian monsoon climate The temporal evolution of African climates based on lake system records Magnitudes and spatial patterns of Holocene hydrologic sensitivities to global climate changes

TUESDAY APRIL 2

$8.45-9.25$ Richard Alley

Abrupt climate changes of the past - and the future? - lessons from the Greenland ice cores.

$9.25-10.05$ Elsa Cortijo

Rapid climatic variability of the Atlantic Ocean and global climate: a focus on the IMAGES program.

10.05 - 10.45 Dominique Raynaud The past record of greenhouse gases: a view in the context of future changes Coffee break

$11.15-11.55$ Juerg Beer

$11.55-12.35$ Greg Zielinski

The role of the sun in climate forcing

Determining the range of variability in the volcanism-climate system through multi-disciplinary evaluations of explosive eruptions over the last 100,000 years

$14.00-14.40$ Thomas Stocker

$14.40-15.20$ Suki Manabe

$15.20-16.00$ Edouard Bard

Past and future reorganizations in the climate system.

The study of abrupt climate change by a coupled ocean atmosphere model Comparing temperatures of the glacial ocean quantified with the alkenone method and simulated by numerical models

16.00 - 18.00 Poster session 2

BANQUET

Wednesday AprIL 22

$8.45-9.25 \quad$ Anne De Vernal

9.24 - 10.05 Sylvie Joussaume

10.05 - 10.45 Sandy Harrison

Coffee break

$11.15-11.55$ Jean Jouzel

11.55 - 12.35 David Rind

Lunch

14.00 - 14.40 Colin Prentice

14.40 - 15.20 Ed Boyle

15.20 - 16.00 Tom Pedersen

Sea-ice, sea-surface salinity and the halo/thermocline structure in the northern North Atlantic: modern vs. last glacial maximum

The Paleoclimate Modeling Intercomparison Project: what can we learn when using several different climate models run under past climates?

How well can we simulate past climates? Evaluating the models using global paleoenvronmental data sets

Water isotopes in precipitation: Data/model comparison for present-day and past climates

TBA

Role of the terrestrial biosphere in Earth system dynamics.

Abrupt climate change and the ocean thermohaline circulation: the search for causes and effects

Influences of oceanic rheostats and amplifiers on atmospheric $\mathrm{pCO}_{2}$ during the late quaternary

\subsection{0 - 18.00 Poster session 3}

Thursdar ApriL 23

8.45 - 9.25 Paul Colinvaux Response of Amazonian and other tropical plant communities to climatic changes

$9.25-10.05$ Rick Battarbee

$10.05-10.45$ Peter DeMenocal of glacial cycles.

Lakes, climate change and the role of paleolimnology: past changes, future threats Holocene variations in subtropical Atlantic Climate and SSTs: a perspective on past social implications of abrupt change

11.15 - 11.55 Jonathan Overpeck Assessing future climate change and its impacts: the role of PAGES data 11.55 - 12.35 Bruno Messerli TBA

Lunch

14.00 - 16.00 Panel Discussion chaired by Chris Rapley

The Poster presentations will be broken into three one day sessions and arranged thematically. The deadline for poster abstract submission is now past.

Late poster abstracts are welcomed until March 15th although inclusion in the published abstracts volume cannot be guaranteed.

\section{Registration:}

The deadline for registration is March 15th, with late registrations possible up to the time of the meeting itself with additional fees imposed.

Pre-registration forms, housing registration forms, and the latest information on the meeting are available by e-mail from the PAGES office (pages@pages.unibe.ch) or from the PAGES website (http://www. pages.unibe.ch/). 